\title{
Privatization and government size
}

\author{
MICHAEL L. MARLOW \\ Department of Economics, California Polytechnic State University, San Luis Obispo, CA 93407
}

\section{Introduction}

A partial list of the proposed constraints on government size includes balanced budget rules, tax reduction, fiscal decentralization and privatization. ${ }^{1}$ Privatization transfers programs from the public sector to the private sector and has received great enthusiasm from many critics of growing government. This paper examines the ability of privatization efforts to control government size.

\section{Model of privatization - government size relation}

Two themes appear in the literature that suggest that privatization is effective in both economic and political arenas for shrinking government. The first theme is that it produces macro-output gains in a world characterized by budget-maximizing bureaucrats. ${ }^{2}$ From research which finds that private production is more efficient than public production, substitution of production from budget-maximizing bureaucrats to profit-maximizing firms is argued to increase resource allocational efficiency. ${ }^{3}$ The second theme is that it solves the special interest problem since it "gives" tangible goods to constituents at the same time as it reduces government spending. Through tax incentives, regulatory changes and asset-sales, privatization is argued to draw constituent support that counters special interests.

I assume that privatization includes only "load shedding," where government eliminates all responsibility for an activity. "Contracting-out" and "vouchers" retain some degree of government control. Missing from the literature is what effect privatization exerts on the government's ability to spend. ${ }^{4}$ Consistent with Friedman (1978), governments are assumed to "spend what they receive plus what other else they can get away with." The total resources government consumes are given by the following short-term operating constraint: $R=T+D$, where $R=$ total funding level, $T=\operatorname{tax}$ level and $D=$ net debt issue. Setting expenditures $E$ equal to the sum of funding sources, government consumes what government receives: $\mathrm{E}=\mathrm{R}$. To lower govern- 
ment size, privatization must shrink the sum total of all funding outlets. ${ }^{6}$ This requires that revenues funding newly-privatized services not be re-channelled into funding a new program or widening an existing program. Unless that funding is removed from the budget, privatization does not unambiguously shrink government size.

\section{Privatization as rent-selling}

Some argue that privatization in Great Britain has been successful. ${ }^{7}$ Success is often attributed to two related devices: (1) offering discounted prices on assetsales and (2) offering tax incentives to foster the demand for privatization. For example, discounts of up to $50 \%$ have been offered for public housing in Great Britain. This suggests that its success is related to the of fering of deep discounts (bribes) which represent income redistribution policy. The larger the discount, the larger the redistribution.

This aspect of privatization appears to represent cases of rent-seeking by constituents, or rent-selling by politicians. The quid pro quo arrangement is clear: politicians trade votes for deeply-discounted housing. Assuming that privatization does not eliminate the funds backing newly-privatized goods, public funds are released that may fund new programs or expand existing programs. In this light, privatization of fers the politician greater ability to rent-sell and a new means of redistributing income without imposing any new funding constraint on government. Privatization may allow politicians to unload old favors (via selling government assets, such as public housing, at discounted prices) and gain funds for new favors. Asset-sales may temporarily expand budget constraints and spending.

\section{Conclusion}

A budget constraint view of government shows that privatization need not alter spending when it is implemented without a rule forbidding re-use of the funding backing newly-privatized programs. Only when these funds are eliminated from the budget process (e.g., tax rebates or permanent deficit reduction) can these funds not back new programs or expand existing programs. This is an important caveat since privatization proposals do not contain such rules. With such rules, privatization can increase allocational efficiency and lead to smaller government size. 


\section{Notes}

1. See Buchanan and Wagner (1977) for balanced budget rules; Friedman (1978) and Marlow and Orzechowski (1988) for tax reduction; Brennan and Buchanan $(1977,1980)$ for fiscal decentralization and Savas (1982), Butler (1985) and President's Commission on Privatization (1988) for privatization.

2. See Miller and Moe (1983) for a discussion of this argument.

3. For example, see Ahlbrandt (1973) and DeAllesi (1974) for studies comparing the efficiencydifferences between private and public productions.

4. Butler (1985: 9) argues that a major reason for why the Reagan Administration had failed to permanently lower government size was due to " . . obsolete weaponary. The initial and fundamental mistake of the administration was its assumption that the only way to contol and cut the budget is to seek legislation to reduce the supply of dollars flowing out of Washington ... The fatal flaw in this supply-side view of the budget process is that it ignores the demand side of the political equation ... A new strategy is needed."

5. The so-called "tax-spend" hypothesis is the subject of many studies. Manage and Marlow (1986), Blackley (1986), Marlow and Manage (1987), Holtz-Eakin et al. (1987) and Ram (1988) provide some evidence in support of the hypothesis. Anderson et al. (1986) provide evidence that the causal direction is in the other direction and von Furstenburg et al. (1986) find evidence of no relation.

6. Note that these funding outlets include inflation which is just one of many forms of taxation. That is, $\mathbf{R}$ is equal to the sum of excise, income, consumption, inflation ... taxes.

7. Butler (1985) argues that by offering discounts of up to $50 \%$ of market value, the Conservatives outbid the Labour Party for key elements of the public housing coalition. During 1979-84, more than 500,000 units had been sold at discount to tenants.

\section{References}

Ahlbrandt, R. (1973). Efficiency in the provision of fire services. Public Choice 18: 1-11.

Anderson, W., Wallace, M.S. and Warner, J.T. (1986). Government spending and taxation: What causes what? Southern Economic Journal 52: 63-639.

Blackley, P.R. (1986). Causality between revenues and expenditures and the size of the federal budget. Public Finance Quarterly 14: 139-156.

Brennan, G. and Buchanan, J.M. (1977). Towards a tax constitution for Leviathan. Journal of Public Economics 8: 255-273.

Brennan, G. and Buchanan, J.M. (1980). The power to tax: Analytical foundations of a fiscal constitution. Cambridge: Cambridge University Press.

Buchanan, J.M. and Wagner, R.E. (1977). Democracy in deficit. New York: Academic Press.

Butler, S.M. (1985). Privatizing federal spending: A strategy to eliminate the deficit. New York: Universe Books.

DeAlessi, L. (1974). An economic analysis of government ownership and regulation: Theory and the evidence from the electric power industry. Public Choice 19: 1-41.

Holtz-Eakin, D., Newey, W. and Rosen, H. (1987). The revenues-expenditures nexus. National Bureau of Economic Research. Paper Number 2180.

Friedman, M. (1978). Tax limitation, inflation and the role of government. Dallas: The Fisher Institute.

Manage, N. and Marlow, M.L. (1986). The causal relation between federal expenditures and receipts. Southern Economic Journal 52: 617-629. 
Marlow, M.L. and Manage, N. (1987). Expenditures and receipts: Testing for causality in state and local government finances. Public Choice 53: 243-255.

Marlow, M.L. and Orzechowski, W. (1988). Controlling Leviathan through tax reduction. Public Choice 58: 237-245.

Miller, T.M. and Moe, G.J. (1983). Bureaucrats, legislators, and the size of government. American Political Science Review 197: 297-322.

President's Commission on Privatization. (1988). Privatization: Toward more effective government. Washington, DC.

Ram, R. (1988). Additional evidence on causality between government revenue and government expenditures. Southern Economic Journal 54: 763-769.

Savas, E.S. (1982). How to shrink government: Privatizing the public sector. Chatham, NJ: Chatham House Publishers.

von Furstenburg, G.M., Green, J.R. and Jeogn, J. (1986). Tax and spend or spend and tax? Review of Economics and Statistics 67: 179-188. 